\title{
KEDUDUKAN KEARIFAN LOKAL DAN PERANAN MASYARAKAT DALAM PENATAAN RUANG DI DAERAH
}

\author{
(Local Wisdom Position and Role of Society in Spatial Planning in the Region)
}

\author{
Eko Noer Kristiyanto \\ Badan Penelitian dan Pengembangan Hukum dan HAM \\ Kementerian Hukum dan HAM RI \\ Jalan HR. Rasuna Said Kav. C-1 , Jakarta 12920 \\ email: ekomaung69@gmail.com
}

Naskah diterima: 14 Juni 2017; revisi: 11 Agustus 2017; disetujui: 21 Agustus 2017

\begin{abstract}
Abstrak
Sebelum pengetahuan modern terkait penataan ruang berkembang pesat, sebenarnya masyarakat asli Indonesia pun telah mengenal konsep penataan ruang yang dalam berbagai diskusi dan penelitian ternyata terbukti efektif dan selaras dengan ilmu pengetahuan modern. Cara pandang serta konsep itulah yang dapat kita artikan sebagai bagian dari kearifan lokal. Tulisan yang disusun dengan tinjauan normatif ini mencoba menjelaskan bagaimana kearifan lokal dapat berperan dalam proses penataan ruang di Indonesia, dan hasil penelitian menunjukkan bahwa di beberapa daerah kearifan lokal sudah diakomodir melalui regulasi daerah, di mana partisipasi masyarakat menjadi sangat penting dalam proses ini, mengakomodir kearifan lokal berarti mengakui juga eksistensi masyarakat hukum adat seperti apa yang dikehendaki oleh konstitusi.

Kata Kunci: kearifan lokal, penataan ruang, regulasi daerah
\end{abstract}

\begin{abstract}
Before the rapid development of modern knowledge on spatial planning, the indigineous people of Indonesia had known spatial planning conception which through many discussions and research has been proven to be effective and in line with modern knowledge. We can perceive this traditional spatial planning perspective and conception as part of the traditional knowledge. This writing, uses normative perspective, tries to explain how the traditional knowledge can take part in spatial planning process in Indonesia. This research shows that in many regions, the local regulation has accomodated the traditional knowledge, where public participation have an important role in the process. This practice can be seen as an act to acknowledge adat society existence as has been expressed by the constitution.
\end{abstract}

Keywords: traditional knowledge, spatial planning, local regulation 


\section{A. Pendahuluan}

Masalah tata ruang, baik dalam ruang lingkup makro maupun mikro, saat ini semakin mendapat perhatian yang cukup serius. Adalah fakta bahwa jumlah penduduk serta kebutuhan yang semakin meningkat, baik secara kualitatif maupun kuantitatif. Demikian juga teknologi yang semakin maju diarahkan sebagai usaha bagi penyediaan sarana dalam memenuhi kebutuhan manusia yang kian meningkat, namun di lain pihak, disadari atau tidak, bahwa pada dasarnya ruang atau lahan yang tersedia masih tetap seperti sediakala. ${ }^{1}$ Selain adanya keterbatasan lahan, permasalahan tata ruang semakin rumit, karena kondisi perekonomian Indonesia pada saat ini semakin hari semakin pesat. Kondisi tersebut perlu diwaspadai, terutama yang berkaitan dengan para pelaku bisnis dalam penggunaan dan pemanfaatan ruang yang semakin besar, juga diakibatkan oleh pertumbuhan penduduk, yang berimbas kepada pertumbuhan kawasan perumahan dan pemukiman. $^{2}$

Dalam Pasal 33 ayat (3) Undang-Undang Dasar 1945 disebutkan bahwa, "Bumidan air dan kekayaan alam yang terkandung di dalamnya dikuasai oleh negara dan dipergunakan sebesar-besarnya kemakmuran rakyat". Realisasi dari pasal ini dituangkan dalam Pasal 2 ayat (2) Undang-Undang Nomor 5 Tahun 1960 tentang Peraturan Dasar Pokok-Pokok Agraria (UUPA), yaitu Negara diberi wewenang untuk mengatur dan menyelenggarakan peruntukan, penggunaan, persediaan dan pemeliharaan bumi, air dan ruang angkasa. Lebih lanjut dalam Pasal 14 UUPA dijelaskan bahwa untuk mencapai apa yang menjadi cita-cita bangsa, maka Pemerintah membuat suatu Rencana Umum mengenai persediaan, peruntukan dan penggunaan bumi, air dan ruang angkasa untuk berbagai kepentingan hidup rakyat dan negara. Terkait hal tersebut, Indonesia telah mengaturnya melalui Peraturan Pemerintah Nomor 16 Tahun 2004 tentang Penatagunaan Tanah dan Undang-Undang Nomor 26 Tahun 2007 tentang Penataan Ruang.

Konsep penataan ruang telah mengalami perkembangan pesat, baik secara teori maupun praktik, bahkan diajarkan secara spesifik di perguruan tinggi. Namun ternyata jauh sebelum ilmu-ilmu modern terkait penataan ruang sebenarnya masyarakat asli Indonesia pun telah mengenal konsep penataan ruang yang dalam berbagai diskusi dan penelitian ternyata terbukti efektif dan selaras dengan ilmu pengetahuan modern, konsep-konsep tradisional ini ternyata masih dipraktikkan oleh masyarakat utamanya masyarakat adat di Indonesia. ${ }^{3}$ Walaupun pengetahuan praktis atau kearifan tradisional secara populer dikenal dengan istilah kearifan budaya lokal, local genius, sistem pengetahuan lokal (SPL), indigenous knowledge, dan lainnya, pengetahuan asli atau kearifan budaya lokal ini pada kenyataannya seringkali terdesak dan terpinggirkan, terutama apabila masyarakat tradisional tersebut hidup di negara yang menerapkan pendekatan pembangunan yang 
bersifat top-down atau bertolak dari pandangan luar komunitas, karena kearifan tradisional seringkali dianggap kurang memenuhi tuntutan rasionalitas dan kemajuan jaman. ${ }^{4}$

Konsep-konsep penataan ruang ala masyarakat ini adalah suatu kearifan lokal yang seyogyanya mampu menunjang dan mendukung pembangunan nasional. Kedekatan manusia secara fisik dan emosional dengan lingkungan sumber daya alam serta terjadinya interaksi dalam suatu sistem yang menghasilkan proses dan hasil proses yang saling berkaitan, saling memberi dan mengambil kemanfaatan dalam kurun waktu yang lama telah melahirkan pengetahuan $^{5}$ yang pada akhirnya akan melahirkan kearifan lokal, utamanya terkait dengan penyikapan manusia terhadap alam. ${ }^{6}$

Eksistensi dan peranan masyarakat dalam hal terkait penentuan kebijakan dalam bidang agraria termasuk diantaranya penataan ruang, dijamin dalam penjelasan UUPA yang menyatakan bahwa hukum adat dijadikan dasar dari pembentukan hukum agraria. ${ }^{7}$ Berbicara hukum adat tentu tak terlepas dari eksistensi masyarakat adat atau masyarakat asli suatu daerah. Masyarakat asli di suatu daerah memiliki cara pandang, wawasan dan konsep terkait lingkungan mereka, meliputi alam, tanah, air, udara dan segala sesuatu yang dapat didefinisikan sebagai ruang dalam peraturan perundang-undangan di Indonesia. ${ }^{8}$ Cara pandang serta konsep itulah yang dapat kita artikan sebagai bagian dari kearifan lokal. Kearifan lokal memiliki cakupan yang lebih luas daripada sekedar pengetahuan tradisional. Kearifan lokal merupakan perwujudan implementasi artikulasi dan pengejawantahan serta bentuk pengetahuan tradisional yang dipahami oleh manusia atau masyarakat yang berinteraksi dengan alam sekitarnya, sehingga kearifan lokal merupakan pengetahuan kebudayaan yang dimiliki kelompok masyarakat tertentu mencakup model-model pengelolaan sumber daya alam secara lestari termasuk bagaimana menjaga hubungan dengan alam melalui pemanfaatan yang bijaksana dan bertanggung jawab. ${ }^{9}$ Dengan demikian kearifan lokal adalah suatu sistem yang mengintegrasikan pengetahuan, budaya dan kelembagaan serta praktik mengelola sumber daya alam. ${ }^{10}$

Kearifan lokal harus bersifat komunal secara kepemilikan dan tidak individual. ${ }^{11}$ Kearifan lokal memiliki sifat keterbukaan dan dapat dipraktikkan dalam kehidupan sepanjang usia komunitas yang ada. Kearifan lokal juga lebih bersifat aplikatif dan pragmatis dengan landasan

4 Nugraheni, Konservasi Hutan dan Pola Pertanian Tradisional Masyarakat Baduy di Banten, Jurnal Studi Indonesia, Vol. 15, No. 1, Maret, 2005), hlm. 14-34.

5 Pengetahuan tersebut meliputi berbagai aspek kehidupan seperti pengaturan permukiman, pengelolaan lingkungan, pertanian, penyediaan makanan, kesehatan, dan cara-cara mengatur pola kehidupannya. Pengetahuan tersebut sangat penting bagi kelangsungan kehidupan mereka dan merupakan bentuk adaptasi terhadap lingkungan hidup yang telah berlangsung lama secara turun temurun.

6 Muh. Aris Marfai, Pengantar Etika Lingkungan dan Kearifan Lokal, (Yogyakarta: Gajah University Press, 2012).

7 Muhammad Bakri, Hak Menguasai Tanah Oleh Negara, (Malang: UB Press, 2011), hlm.68.

8 Ruang menurut Undang-Undang Nomor 26 Tahun 2007 tentang Penataan Ruang adalah wadah yang meliputi ruang darat, ruang laut, dan ruang udara termasuk ruang di dalam bumi sebagai satu kesatuan wilayah, tempat manusia dan makluk hidup, melakukan kegiatan, dan memelihara kelangsungan hidupnya.

9 Suhartini, Kearifan Lokal dan Konservasi Keanekaragaman Hayati, (Yogyakarta: UGM Press, 2009)

10 Ibid.

11 Keraf, Etika Lingkungan, Kompas, 2005, dalam lihat Muh. Aris Marfai, Pengantar Etika Lingkungan dan Kearifan Lokal, (Yogyakarta: Gajah University Press, 2012). 
filosofi yang dipahami bersama. Kearifan lokal menyangkut bagaimana berhubungan secara baik dengan semua isi alam. ${ }^{12}$ Kearifan lokal lebih bersifat holistik menyangkut kehidupan mikrokosmos dan makrokosmos. Kearifan lokal merupakan refleksi moralitas yang didasarkan pada prinsip tabu dan hanya dapat dipahami oleh kerangka tradisional. Kearifan lokal juga memiliki sifat-sifat lokal dari refleksi karakteristik komunitas lokal. ${ }^{13}$ Corak komunal, sosial, serta kolektif dalam kearifan lokal ini selaras dengan prinsip dalam UUPA juga erat kaitannya dengan hukum adat. Definisi terkait kearifan lokal pun tercantum dalam Undang-Undang Nomor 32 Tahun 2009 tentang Perlindungan dan Pengelolaan Lingkungan Hidup, dijelaskan bahwa kearifan lokal adalah nilai-nilai luhur yang berlaku dalam tata kehidupan masyarakat untuk antara lain melindungi dan mengelola lingkungan hidup secara lestari. Lebih dari itu, pengakuan terhadap kearifan lokal pun adalah kehendak konstitusi sebagaimana diatur dalam Pasal 18B ayat (2) UUD 1945. Kearifan lokal dianggap bagian tidak terpisahkan dari kesatuan Masyarakat Hukum Adat, sehingga selama masih relevan dan tak bertentangan dengan peraturan perundang-undangan yang berlaku maka pemerintah wajib mempertimbangkannya dalam pembentukan regulasi di daerah, Perda menjadi salah satu dasar hukum untuk menunjukan bahwa kesatuan masyarakat hukum adat itu masih eksis.
Paparan di atas menunjukkan bahwa masyarakat asli masyarakat adat memiliki peran dan kedudukan yang strategis di era otonomi daerah, peraturan perundang-undangan menjamin keberadaan dan eksistensi mereka, termasuk hak mereka untuk berpartisipasi dalam proses pengambilan kebijakan. Kebijakan terkait penataan ruang seringkali menimbulkan pro kontra serta problematika, walau secara formil prosedural prosesnya dapat dikatakan sudah tepat namun apakah benar-benar telah mengakomodir aspirasi serta kearifan lokal masyarakat? Karena secara teoritis menurut sudut pandang sosiologis hukum yang dapat diterima dan dilaksanakan masyarakat seharusnya tidak menimbulkan gejolak. Tulisan ini mengemukakan permasalahan yaitu bagaimana peranan masyarakat beserta kearifan lokal mereka dalam penataan ruang, khususnya di daerah.

\section{B. Metode Penelitian}

Metode penelitian yang digunakan dalam penulisan ini adalah metode penelitian hukum normatif, metode penelitian hukum normatif pada dasarnya meneliti kaidah-kaidah hukum dan asas-asas hukum, ${ }^{14}$ penelitian normatif akan mencoba menemukan suatu aturan hukum, prinsip hukum, maupun doktrin hukum guna menjawab isu hukum yang dihadapi, ${ }^{15}$ khususnya terkait teori-teori

12 Ibid.

13 Ibid.

14 Bagir Manan, Penelitian Terapan di Bidang Hukum, (makalah, disampaikan pada Lokakarya Peranan Naskah Akademis Dalam Penyusunan Peraturan Perundang-undangan, BPHN, Jakarta, 9 - 11 November 1993), hlm.7. Soerjono Soekanto dan Sri Mamudji menyatakan bahwa penelitian hukum normatif atau penelitian hukum kepustakaan merupakan penelitian hukum yang dilakukan dengan cara meneliti bahan pustaka atau data sekunder belaka yaitu dengan cara menelaah permasalahan dengan berpedoman pada data sekunder lihat Soerjono Soekanto dan Sri Mamudji, Penelitian Hukum Normatif: Suatu Tinjauan Singkat, (Jakarta: Raja Grafindo Persada, 2001).

15 Peter Mahmud Marzuki, Penelitian Hukum, (Jakarta: Kencana, 2010), hlm. 35. 
tentang penelitian ini menelaah permasalahan dengan berpedoman pada data sekunder yang dilakukan dengan studi pustaka terhadap bahan-bahan hukum dan bahan non-hukum yang berkaitan dengan judul penelitian. Bahan hukum sekunder yang dimaksud adalah doktrin, ajaran para ahli, hasil karya ilmiah para ahli, berita-berita dan hasil wawancara pihak terkait yang diperoleh dari surat kabar serta situs-situs internet yang relevan dengan judul penelitian.

Data di atas dikumpulkan melalui studi kepustakaan (library research), penelurusan melalui media internet (online research), dalam hal ini penulis menitikberatkan dalam konteks bagaimana kearifan lokal masyarakat terkait penataan ruang dapat diakomodir oleh hukum nasional Indonesia. Adapun penulisan difokuskan dalam konteks pembentukan hukum yang mengakomodir partisipasi dan peran serta masyarakat termasuk kearifan lokal yang dimiliki oleh masyarakat. Penelitian pun akan mencoba menjelaskan bagaimana peranan kearifan lokal menurut peraturan perundang-undangan terkait penataan ruang di Indonesia.

\section{Pembahasan}

\section{Kearifan Lokal dalam Pembentukan Peraturan Perundang-undangan Terkait Penataan Ruang}

Dalam pengertian kamus, kearifan lokal (local wisdom) terdiri dari 2 (dua) kata: kearifan (wisdom) dan lokal (local). Dalam Kamus Inggris-Indonesia John $M$. Echols dan Hassan Syadily, local berarti setempat, sedangkan wisdom (kearifan) sama dengan kebijaksanaan. Secara umum maka local wisdom (kearifan setempat) dapat dipahami sebagai gagasan-gagasan setempat (local) yang bersifat bijaksana, penuh kearifan, bernilai baik, yang tertanam dan diikuti oleh anggota masyarakatnya. ${ }^{16}$ Kearifan lokal itu terdapat dalam masyarakat, komunitas, dan individu. Dengan demikian kearifan lokal merupakan pandangan dan pengetahuan tradisional yang menjadi acuan dalam berperilaku dan telah dipraktikkan secara turun-temurun untuk memenuhi kebutuhan dan tantangan dalam kehidupan suatu masyarakat. Kearifan lokal berfungsi dan bermakna dalam masyarakat baik dalam pelestarian sumber daya alam dan manusia, adat dan budaya, serta bermanfaat untuk kehidupan.

Masyarakat asli di suatu daerah memiliki cara pandang, wawasan dan konsep terkait lingkungan mereka, cara pandang serta konsep itulah yang dapat kita artikan sebagai bagian dari kearifan lokal. Kearifan lokal memiliki cakupan yang lebih luas daripada sekedar pengetahuan tradisional. Kearifan lokal merupakan perwujudan implementasi artikulasi dan pengejawantahan serta bentuk pengetahuan tradisional yang dipahami oleh manusia atau masyarakat yang berinteraksi dengan alam sekitarnya, sehingga kearifan lokal merupakan pengetahuan kebudayaan yang dimiliki kelompok masyarakat tertentu mencakup model-model pengelolaan sumber daya alam secara lestari termasuk bagaimana menjaga hubungan dengan alam melalui pemanfaatan yang bijaksana dan bertanggung jawab. ${ }^{17}$ Dengan demikian kearifan lokal adalah suatu sistem yang mengintegrasikan

16 Sartini, Menggali Kearifan Lokal Nusantara Sebuah Kajian Filsafati, Jurnal Filsafat, Jilid 37, Nomor 2, Agustus, 2004.

17 Suhartini, Kearifan Lokal dan Konservasi Keanekaragaman Hayati, (Yogyakarta: UGM, 2009). 
pengetahuan, budaya dan kelembagaan serta praktik mengelola sumber daya alam. ${ }^{18}$

Kearifan lokal dapat dipilah menjadi 2 (dua) yaitu kearifan sosial dan kearifan ekologi. ${ }^{19}$ Kearifan sosial menekankan pada pembentukan makhluk sosial menjadi lebih arif dan bijaksana. ${ }^{20}$ Kearifan ekologi merupakan pedoman manusia agar arif dalam berinteraksi dengan lingkungan alam biofisik dan supernatural. Kearifan lokal ekologi memandang bahwa manusia merupakan bagian dari alam. ${ }^{21}$ Maka dalam hal ini, kearifan terkait penataan ruang adalah termasuk dalam kearifan ekologi. Kearifan lokal dalam konteks penataan ruang sangat penting karena asas-asas dalam Undang-Undang Penataan Ruang selaras dengan konsep-konsep kearifan lokal. Secara fungsional kearifan lokal sangat berkaitan dengan harmoni, keseimbangan dan keberlanjutan. ${ }^{22}$

Berbicara tentang kearifan lokal maka kita akan sangat erat kaitannya dengan masyarakat asli, lokal, atau masyarakat adat. Berangkat dari pemahaman bersama bahwa upaya mewujudkan penegakan hak asasi manusia (HAM) bagi masyarakat adat yang diemban oleh Negara adalah dengan memberikan perlindungan hukum bagi masyarakat adat sebagaimana diamanatkan dalam konstitusi. Landasan konstitusional perlindungan, pengakuan, dan penghormatan terhadap masyarakat hukum adat terdapat pada Pasal 18, Pasal 18 B ayat (2) Undang-Undang Dasar 1945 berbunyi: "Negara mengakui dan menghormati kesatuan-kesatuan masyarakat hukum adat beserta hak-hak tradisionalnya sepanjang masih hidup dan sesuai dengan perkembangan masyarakat dan prinsip Negara Kesatuan Republik Indonesia, yang diatur dalam undangundang." Keberadaan dan eksistensi masyarakat dalam konstitusi diatur juga dalam Pasal 18B ayat (3), Pasal 281 ayat (3), serta pasal 32 ayat (1) dan (92) UUD 1945.

Terkait eksistensi masyarakat dan kerifan lokal dikenal beberapa kearifan lokal nusantara seperti: Alam Takambang Jadi Guru (Minangkabau), Banjar Sari (Jakarta), Nyabuk Gunung (Sunda), Bersih Desa (Jawa), Hamemayu Hayuning Bawono (Yogyakarta), Karah (Surabaya), Tri Hita Karana (Bali), Awig Awig (Bali dan NTT), Kassi Kassi (Makasar), dan Sasi (Maluku). ${ }^{23}$

Kearifan-kearifan lokal tersebut dianggap baik terbukti dari eksistensinya, dan kearifan lokal masyarakat tersebut ternyata mampu menyeimbangkan kondisi alam dan ekosistem. Kearifan-kearifan lokal tersebut melekat dalam eksistensi dan kehidupan masyarakat setempat, sehingga layak dikatakan sebagai kearifan asli bangsa Indonesia. Masyarakat adat hidup dengan kearifan lokal mereka, oleh karena itu jika Negara serius melindungi masyarakat adat, maka harus pula melindungi dan menjaga eksistensi kearifan lokal mereka.

Berbicara tentang perlindungan hukum masyarakat adat tentunya harus berangkat dari hak-hak masyarakat adat dalam kaitannya

\footnotetext{
Ibid.

Wayan Suja, Kearifan Lokal Sains Asli Bali, (Surabaya: Paramita, 2010).

Ibid.

Ibid..

22 I Wayan Geriya, Konsep dan Strategi Revitalisasi Kearifan Lokal, (Denpasar: UPT Penerbit Universitas Udayana, 2007).

23 Nyoman Wijana, Pengelolaan Lingkungan Hidup, (Yogyakarta: Plantaxia, 2016), hlm. 3.
} 
dengan pengakuan dan pengaturannya di dalam hukum nasional. Untuk itu hal pertama yang harus dilakukan adalah mengetahui posisi dan kedudukan masyarakat adat itu sendiri sebagai subyek hukum yang memiliki hak-hak adat tersebut di dalam kerangka Negara Kesatuan Republik Indonesia. ${ }^{24}$ Apakah negara mengakui dan menghormati atau tidak keberadaan dari masyarakat adat tersebut dengan segala hakhak tradisional yang melekat padanya. Serta bagaimana politik hukum nasional terhadap upaya perlindungan hukum terhadap hak-hak masyarakat adat berdasarkan UUD NRI 1945. ${ }^{25}$

Jika negara berkomitmen untuk melindungi masyarakat adat, maka negara pun harus melindungi pula segala sesuatu yang melekat pada mereka termasuk kearifan lokal yang masih terjaga eksistensinya. ${ }^{26}$

Penataan Ruang adalah suatu sistem proses perencanaan tata ruang, pemanfaatan ruang, dan pengendalian pemanfaatan ruang. ${ }^{27}$
Pengertian Tata Ruang itu sendiri mengandung cakupan arti yang sangat luas yaitu bahwa tata ruang adalah wujud struktur ruang dan pola ruang. ${ }^{28}$ Dalam peraturan perundang-undangan sebelumnya disebutkan "Tata ruang adalah wujud struktural dan pola pemanfaatan ruang baik direncanakan maupun tidak." ${ }^{29}$ Sementara ruang itu, ruang sendiri adalah: "Wadah yang meliputi suang daratan, ruang lautan, ruang udara sebagai satu kesatuan wilayah tempat manusia dan makhluk lainnya hidup dan melakukan kegiatan serta memelihara kelangsungan hidupnya." ${ }^{30}$

Sehubungan dengan hal ini, di dalam penjelasan umum dari Undang-Undang Nomor 26 Tahun 2007 tentang Penataan Ruang disebutkan sebagai berikut:

Ruang yang meliputi ruang darat, ruang laut, dan ruang udara, termasuk ruang di dalam bumi, sebagai tempat manusia dan makhluk hidup, melakukan kegiatan, dan memelihara kelangsungan hidupnya, pada dasarnya

24 Perlindungan hukum secara maksimal baik dari segi materil maupun spiritual atas penerapan politik pembangunan perlu dikedepankan. Dengan demikian diharapkan tidak ada lagi pelanggaran hak-hak masyarakat adat baik di bidang ekonomi, politik, hukum, maupun sosial dan budaya. Karena pelanggaran itu pula yang seringkali memicu konflik antara masyarakat adat, baik dengan pemerintah lokal, pemerintah pusat, maupun pihak swasta.

25 Dr. Wicipto Setiadi, S.H.,M.H., Sambutan Pembukan Kepala Badan Pembinaan Hukum Nasional pada Seminar Tentang Arah Perlindungan Hukum Bagi Masyarakat Adat Dalam Sistem Hukum Nasional, Malang, 12 Mei 2011.

26 Pengakuan dan penghormatan terhadap keberadaan Masyarakat Hukum Adat (MHA) tidak dapat dilepaskan dari pengaturan hukumnya. Polemik mengenai keberadaan MHA ditengarai bersumber karena tidak adanya produk hukum atau peraturan perundangan yang mengatur mengenai keberadaan MHA tersebut. Produk hukum perundang-undangan yang mengatur mengenai adat ini, hanya tampak sebagai minoritas dari sistem hukum yang tamak dan tidak berpihak kepada MHA. Atau dalam kata lain, keberadaan masyarakat adat sebagai masyarakat asli suatu daerah menjadi terpinggirkan dan semakin tergerus keberadaannya. Pengaturan tentang MHA telah tertuang dalam Pasal 18B ayat (2), pengakuan bahwa negara mengakui dan menghormati kesatuankesatuan masyarakat hukum adat beserta hak-hak tradisionalnya dan juga dalam BAB XA tentang Hak Asasi Manusia pada Pasal 28I ayat (3) tentang pengakuan identitas budaya dan hak masyarakat tradisional. Pasal-pasal tersebut tampak adanya pengakuan atas keberadaan Masyarakat Adat dan tatanan adatnya dan memberikan peluang bahwa sangat dimungkinkan pengaturannya melalui undang-undang.

27 Pasal 1 ayat (5) Undang-Undang Nomor 26 Tahun 2007 tentang Penataan Ruang (Lembaran Negara Republik Indonesia Tahun 2007 Nomor 68).

28 Undang-Undang Nomor 26 Tahun 2007 tentang Penataan Ruang (Lembaran Negara Republik Indonesia Tahun 2007 Nomor 68).

29 Pasal 1 Undang-Undang Nomor 24 Tahun 1992 tentang Penataan Ruang (Lembaran Negara Republik Indonesia Tahun 1992 Nomor 115).

30 Ibid., Pasal 1 ayat (1). 
ketersediaannya tidak tak terbatas. Berkaitan dengan hal tersebut, dan untuk mewujudkan ruang wilayah nasional yang aman, nyaman, produktif, dan berkelanjutan berlandaskan Wawasan Nusantara dan Ketahanan Nasional, undang-undang ini mengamanatkan perlunya dilakukan penataan ruang yang dapat mengharmonisasikan lingkungan alam dan lingkungan buatan, yang mampu mewujudkan keterpaduan penggunaan sumber daya alamdan sumber daya buatan, serta yang dapat mendapat perlindungan terhadap fungsi ruang dan pencegahan dampak negatif terhadap lingkungan hidup akibat pemanfaatan ruang. Kaidah penataan ruang ini harus dapat diterapkan dan diwujudkan dalam setiap proses perencanaan tata ruang wilayah.

Dengan demikian, jelaslah bahwa penataan ruang mengandung dimensi kegiatan yang sangat luas. Oleh sebab itu, tidaklah mengherankan apabila banyak dijumpai adanya berbagai peraturan perundang-undangan yang berkaitan dengan hal tersebut. Bila masalah yang berkaitan dengan penataan ruang diletakkan dalam konteks Negara Hukum Kesejahteraan sebagaimana yang dianut oleh Negara Hukum Kesejahteraan sebagaimana dianut oleh Negara Kesatuan Republik Indonesia, dapat dikatakan bahwa kebijakan penataan ruang yang tertuang dalam Undang-Undang Nomor 24 Tahun 1992 sangat relevan dengan paham Negara Hukum Kesejahteraan. ${ }^{31} \mathrm{Hal}$ ini dapat dilihat dalam penjelasan umum angka 1 dari undang-undang tersebut diatas yang menyebutkan sebagai berikut: Ruang wilayah Negara Kesatuan Republik Indonesia, baik sebagai kesatuan wadah yang meliputi ruang darat, ruang laut, dan ruang udara, termasuk ruang di dalam bumi, maupun sebagi sumber daya, merupakan karunia Tuhan Yang Maha Esa kepada bangsa Indonesia yang perlu disyukuri, dilindungi, dan dikelola secara berkelanjutan untuk sebesar-besarnya kemakmuran kemakmuran rakyatsesuai amanat yang terkandung dalam Pasal 33 ayat (3) Undang-Undang Dasar Negara Republik Indonesia Tahun 1945, serta makna yang terkandung dalamfalsafah dan dasar negara Pancasila. Untuk mewujudkan amanat Pasal 33 ayat (3) Undang-Undang Dasar Negara Republik Indonesia Tahun 1945 tersebut, Undang-Undang tentang Penataan Ruang ini menyatakan bahwa negara menyelenggarakan penataan ruang, yang pelaksanaan wewenangnya dilakukan oleh pemerintah daerah tetap menghormati hak yang dipilih oleh setiap orang.

Orientasi penataan ruang adalah dalam rangka mewujudkan ruang wilayah nasional yang aman, nyaman, produktif, dan berkelanjutan berlandaskan wawasan nusantara dan ketahanan nasional. ${ }^{32} \mathrm{Hal}$ penting lain yang perlu diperhatikan adalah bahwa UndangUndang Nomor 26 Tahun 2007 tentang Penataan Ruang menghendaki perlindungan fungsi ruang dan pencegahan dampak negatif terhadap lingkungan akibat pemanfaatan ruang. ${ }^{33}$ Sebuah tujuan dan konsep yang selaras dengan kearifan lokal masyarakat. 


\section{Partisipasi Masyarakat Dalam Penataan Ruang}

Partisipasi dapat diartikan sebagai ikut serta, berperan serta dalam suatu kegiatan, mulai dari perencanaan sampai dengan evaluasi. Partisipasi masyarakat dalam proses pembentukan peraturan perundang-undangan dapat dikategorikan sebagai partisipasi politik. ${ }^{34}$ Partisipasi politik diartikan sebagai kegiatan warga negara sipil (private citizen) yang bertujuan memengaruhi pengambilan keputusan oleh pemerintah. ${ }^{35}$

Partisipasi masyarakat diartikan sebagai keikutsertaan masyarakat, baik secara individual maupun kelompok, secara aktif dalam penentuan kebijakan publik atau peraturan perundang-undangan. Partisipasi merupakan ruang bagi masyarakat untuk melakukan negosiasi dalam proses perumusan kebijakan terutama yang berdampak langsung terhadap kehidupan masyarakat. ${ }^{36}$ Selain memberi ruang bagi kepada masyarakat untuk mengetahui sejak dini kemungkinan implikasi pembentukan peraturan perundang-undangan, partisipasi diperlukan guna memastikan bahwa kepentingan masyarakat tidak diabaikan oleh pembentuk peraturan. ${ }^{37}$ Terlebih bahwa pada hakikatnya seluruh regulasi yang terbentuk diarahkan kepada terwujudnya tatanan kehidupan yang bermanfaat bagi kepentingan rakyat. $^{38}$

Pada dasarnya partisipasi masyarakat bukanlah suatu konsep yang baku. Namun hanya sekedar "a means to an end", jadi bukan tujuan akhir itu sendiri. ${ }^{39}$ Tujuan sebenarnya adalah "pengaruh yang berarti" terhadap proses pemerintahan dalam arti luas terutama yang berkenaan dengan pengelolaan sumber daya publik. Dalam konsep participatory democracy dinyatakan bahwa manusia pada hakekatnya mampu menyelaraskan kepentingan pribadinya dengan kepentingan sosial. Penyelarasan kedua macam kepentingan tersebut dapat terwujudjika proses pengambilan keputusan menyediakan kesempatan seluas-luasnya kepada mereka untuk mengungkapkan kepentingan dan pandangan mereka. Proses pengambilan keputusan yang menyediakan ruang bagi pemangku kepentingan untuk berperan serta di dalamnya, sehingga perbedaan kepentingan antara kelompok satu dan yang lainnya dapat dikomunikasikan. ${ }^{40}$

Menurut Koesnadi Hardjasoemantri, pokok pikiran yang melandasi perlunya peran serta masyarakat dapat dikemukakan sebagai berikut: ${ }^{41}$

34 Hamzah Halim dan Kemal Redindo, Cara Praktis Menyusun dan Merancang Peraturan Daerah, (Jakarta: Kencana Prenada Media Group, 2009), hlm. 108.

35 Samuel Huntington dan Joan Nelson, Partisipasi Politik di Negara Berkembang, (Jakarta: Rineka Cipta, 1994).

36 Saldi Isra, Pergeseran Fungsi Legislasi, (Jakarta: PT. Raja Grafindo Persada, 2010), hlm. 282-283.

37 Ibid.

38 Pataniari Siahaan, Politik Hukum Pembentukan Undang-Undang Pasca Amandemen UUD 1945, (Jakarta: Konpress, 2012), hlm. 35.

39 Mas Achmad Santosa, Good Governance dan Hukum Lingkungan, (Jakarta: ICEL, 2001), hlm.48.

40 Mas Achmad Santosa dan Arimbi HP, Peran Serta Masyarakat Dalam Pengelolaan Lingkungan, (Jakarta: WALHI dan YLBHI, 1933).

41 Abdul Gofur Anshori dan Sobirin Malian, Membangun Hukum Indonesia Pidato Pengukuhan Guru Besar Ilmu Hukum, (Yogyakarta: Kresi Total Media, 2008), lihat juga Jurnal Rechtsvinding Volume 4, Agustus, 2015, hlm. 299-300. 
1) Memberi Informasi Kepada Pemerintah

Peran serta masyarakat terutama akan dapat menambah perbendaharaan pengetahuan mengenai suatu aspek tertentu yang diperoleh dari pengetahuan khusus masyarakat itu sendiri. Peran serta masyarakat sangat diperlukan untuk memberi masukan kepada pemerintah tentang masalah yang dapat ditimbulkan oleh suatu rencana pemerintah dengan berbagai konsekuensinya. Informasi yang didapat dari masyarakat akan menambah informasi dan masukan bagi proses pengambilan keputusan yang dilakukan oleh pemerintah akan dapat meningkatkan kualitas keputusan tersebut.

2) Meningkatkan Kesediaan Masyarakat Untuk Menerima Keputusan

Seseorang yang telah memperoleh kesempatan untuk berperan serta dalam proses pengambilan keputusan, akan cenderung untuk memperlihatkan sikap menerima dan menyesuaikan diri dengan keputusan tersebut.

3) Membantu Perlindungan Hukum

Bila sebuah keputusan akhir diambil dengan memperhatikan keberatan-keberatan yang diajukan oleh masyarakat selama proses pengambilan keputusan berlangsung, maka dalam banyak hal tak akan ada keperluan untuk mengajukan perkara ke pengadilan.

Secara teori, partisipasi memang menghendaki partisipasi masyarakat secara aktif, terlebih di era otonomi daerah seperti sekarang, maka kemandirian dan menentukan nasib sendirimenjadi sangat penting. Masyarakat sebagai penghuni asli teritori diharapkan mampu menentukan arah dan kebijakan untuk kesejahteraan mereka sendiri. Namun tentunya arah dan kebijakan tersebut haruslah selaras dengan kebijakan nasional, baik program maupun regulasi. Secara hukum, partisipasi masyarakat pun dijamin dan harus diakomodir dalam pembentukan regulasi. Setidaknya terdapat 6 (enam) Undang-Undang yang terkait dengan partisipasi publik/ masyarakat, 6 (enam) Undang-Undang tersebut yaitu:

1) Undang-Undang Nomor 26 Tahun 2007 tentang Penataan Ruang

2) Undang-Undang Nomor 14 Tahun 2008 tentang Keterbukaan Informasi Publik;

3) Undang-Undang Nomor 32 Tahun 2009 tentang Perlindungan dan Pengelolaan Lingkungan Hidup;

4) Undang-Undang Nomor 12 Tahun 2011 tentang Pembentukan Peraturan Perundangundangan;

5) Undang-Undang Nomor 6 Tahun 2014 tentang Desa;

6) Undang-Undang Nomor 23 Tahun 2014 tentang Pemerintahan Daerah.

Untuk menyerap dan mentransformasikan kearifan lokal ke dalam sistem hukum formil maka hal yang paling logis adalah mengakomodirnya dalam peraturan daerah. Undang-Undang Pemerintahan Daerah menghendaki dan mewajibkan adanya partisipasi masyarakat dalam pembentukan perda, begitupun UndangUndang Keterbukaan Informasi Publik yang menghendaki keterlibatan, peran serta dan partisipasi di tingkat daerah, termasuk tingkat peraturan daerah yang dimaksud dalam Undang-Undang Pembentukan Peraturan Perundang-Undangan. ${ }^{42}$

42 Mengacu pada kenyataan penyusunan Raperda yang dilakukan selama ini, keterlibatan publik atau masyarakat jelas merupakan suatu keharusan, meski bukan merupakan kewajiban hukum. Jika pun ada pelibatan publik, 
Proses pembentukan hukum suatu negara tidak bisa dilepaskan dari "cara berhukum" bangsa yang bersangkutan. ${ }^{43} \mathrm{Hal}$ ini akan dipengaruhi oleh politik hukum bangsa ini, utamanya penguasa. Politik hukum memuat arah kebijakan yang akan diterapkan dengan menetapkan tujuan dan isi dari sebuah peraturan perundang-undangan. ${ }^{44}$ Dalam konteks ini pula maka peran serta masyarakat dalam Undang-undang Nomor 26 Tahun 2007 diatur secara khusus dalam BAB VIII yang berisi tentang Hak. Kewajiban dan Peran Masyarakat.

Dalam penataan ruang, setiap orang berhak untuk: ${ }^{45}$

1) mengetahui rencana tata ruang;

2) menikmati pertambahan nilai ruang sebagai akibat penataan ruang;

3) memperoleh penggantian yang layak atas kerugian yang timbul akibat pelaksanaan kegiatan pembangunan yang sesuai dengan rencana tata ruang;

4) mengajukan keberatan kepada pejabat berwenang terhadap pembangunan yang tidak sesuai dengan rencana tata ruang di wilayahnya;

5) mengajukan tuntutan pembatalan izin dan penghentian pembangunan yang tidak sesuai dengan rencana tata ruang kepada pejabat berwenang; dan

6) mengajukan gugatan ganti kerugian kepada pemerintah dan/atau pemegang izin apabila kegiatan pembangunan yang tidak sesuai dengan rencana tata ruang menimbulkan kerugian.

Kemudian di dalam penyelenggaraan penataan ruang yang dilakukan oleh pemerintah dibutuhkan partisipasi masyarakat, melalui: ${ }^{46}$

1) partisipasi dalam penyusunan rencana tata ruang, adalah suatu proses untuk menentukan struktur ruang dan pola ruang yang meliputi penyusunan dan penetapan rencana tata ruang;

2) partisipasi dalam pemanfaatan ruang, adalah upaya untuk mewujudkan struktur ruang dan pola ruang sesuai dengan rencana tata ruang melalui penyusunan dan pelaksanaan program beserta pembiayaannya;

3) partisipasidalam pengendalian pemanfaatan ruang, adalah upaya untuk mewujudkan tertib tata ruang.

Secara teknis maka peran serta dan partisipasi masyarakat dalam penataan ruang dapat kita lihat melalui Peraturan Pemerintah

hal tersebut cenderung hasil dari pendekatan dan terkadang 'tekanan' dari publik - baik itu ornop maupun masyarakat yang berkepentingan langsung terhadap peraturan tersebut. Namun demikian, dalam pelibatan publik ini masih belum ada jaminan apa yang menjadi aspirasi masyarakat akan tertulis dalam produk final Perda dapat diimplementasikan. Penyusunan peraturan daerah yang lebih menekankan pada proses teknisnya, dan bukan pada substansi sehingga kepentingan yang dibawa oleh Perda tersebut belum tentu bermanfaat. Pihak-pihak yang seharusnya dilibatkan malah tidak diikutkan sebagai indikator timbulnya pertentangan. Hal ini pada akhirnya tidak jarang melahirkan konflik yang berkepanjangan dan berakibat menjadi penghambat dalam pengimplementasiannya.

43 Anis Ibrahim, Legislasi dan Demokrasi (Malang: In-Trans Publishing, 2008), hlm. 82.

44 Mahfud MD, Politik Hukum di Indonesia, (Jakarta: PT. Raja Grafindo Persada, 2009), hlm. 1.

45 BAB VIII, Pasal 60, Undang-Undang Nomor 26 Tahun 2007 tentang Penataan Ruang (Lembaran Negara Republik Indonesia Tahun 2007 Nomor 68).

46 Bab VIII, Pasal 65 Undang-Undang RI Nomor 26 Tahun 2007 tentang Penataan Ruang (Lembaran Negara Republik Indonesia Tahun 2007 Nomor 68). 
Nomor 68 Tahun 2010 tentang Bentuk dan Tata Cara Peran Masyarakat dalam Penataan Ruang.

Dalam peraturan pemerintah tersebut ditentukan peran masyarakat dalam penataan ruang yang dilakukan pada tahap: ${ }^{47}$

1) perencanaan tata ruang;

2) pemanfaatan ruang; dan

3) pengendalian pemanfaatan ruang.

Bentuk peran masyarakat dalam perencanaan tata ruang berupa:48

1) Memberi masukan mengenai:

a) persiapan penyusunan rencana tata ruang;

b) pengidentifikasian potensi dan masalah pembangunan wilayah atau kawasan;

c) perumusan konsepsi rencana tata ruang; dan/atau

d) penetapan rencana tata ruang.

2) Melalui kerja sama dengan pemerintah, pemerintah daerah, dan/atau sesama unsur masyarakat dalam perencanaan tata ruang.

Pemerintah dan/atau pemerintah daerah dalam perencanaan tata ruang dapat secara aktif melibatkan masyarakat. Yang mana masyarakat tersebut adalah yang terkena dampak langsung dari kegiatan penataan ruang, yang memiliki keahlian di bidang penataan ruang, dan/atau yang kegiatan pokoknya di bidang penataan ruang.

Dari penjelasan di atas maka masyarakat dapat memberi masukan sejak proses perencanaan dengan memberi masukan- masukan, masyarakat asli yang dianggap memahami konsep tata ruang berdasar kearifan lokal setempat jelas termasuk pihak yang wajib dilibatkan karena masyarakat asli ini memenuhi ketentuan sebagai pihak yang memahami dan ahli terkait tata ruang berdasarkan perspektif kearifan lokal setempat. ${ }^{49}$

Sementara redaksional terkait kearifan lokal secara eksplisit terdapat dalam Pasal 9 ayat (3) dan ayat (4) yang menyatakan:

Di dalam pemanfaatan ruang peran masyarakat berupa: ${ }^{50}$

1) masukan mengenai kebijakan pemanfaatan ruang;

2) kerja sama dengan Pemerintah, pemerintah daerah, dan/atau sesama unsur masyarakat dalam pemanfaatan ruang;

3) kegiatan memanfaatkan ruang yang sesuai dengan kearifan lokal dan rencana tata ruang yang telah ditetapkan;

4) peningkatan efisiensi, efektivitas, dan keserasian dalam pemanfaatan ruang darat, ruang laut, ruang udara, dan ruang di dalam bumi dengan memperhatikan kearifan lokal serta sesuai dengan ketentuan peraturan perundangundangan;

5) kegiatan menjaga kepentingan pertahanan dan keamanan serta memelihara dan meningkatkan kelestarian fungsi lingkungan hidup dan sumber daya alam; dan

Bab II, Pasal 5 Peraturan Pemerintah Nomor 68 Tahun 2010 tentang Bentuk dan Tata Cara Peran Masyarakat Dalam Penataan Ruang.

Ibid., Bab II, Pasal 6.

9 Peraturan ternyata menjamin bahwa siapapun, tidak harus praktisi/akademisi yang memahami tata ruang dari ilmu modern namun siapapun orangnya asalkan ahli dalam bidang penataan ruang, dalam konteks ini maka ahli berdasar ilmu yang berpegangan pada kearifan lokal pun termasuk.

50 Ibid, Pasal 9. 
6) kegiatan investasi dalam pemanfaatan.

Rumusan ayat (3) yang menyatakan "sesuai dengan kearifan lokal dan rencana tata ruang" menunjukkan bahwa regulasi penataan ruang telah memberi pengakuan kepada kearifan lokal masyarakat. Sehingga eksistensi kearifan lokal akan semakin kuat karena selain pemanfaatan ruang harus sesuai dengan rencana tata ruang yang telah ada, dan wajib pula menyesuaikan dengan kearifan lokal. Rencana Tata Ruang yang dimaksud adalah Rencana Tata Ruang dari Pusat yang sinergis dan selaras dengan Rencana Tata Ruang Daerah. Sesuai dengan Undang-Undang Nomor 26 Tahun 2007, maka penataan ruang dilakukan secara berjenjang dan komplementer sesuai dengan kewenangan administratif, yaitu dalam bentuk RTRWN (Rencana Tata Ruang Wilayah Nasional), RTRW Provinsi (Rencana Tata Ruang Wilayah Provinsi), dan RTRW Kabupaten/ Kota (Rencana Tata Ruang Wilayah Kabupaten/ Kota), serta rencana-rencana yang sifatnya lebih rinci seperti RDTR (Rencana Detail Tata Ruang).

\section{Mengintegrasikan Kearifan Lokal Dalam Penataan Ruang Melalui Partisipasi Masyarakat}

Dalam rangka tertib perencanaan tata ruang maka peraturan di tingkat pusat ataupun daerah haruslah sinergis dan komprehensif. Tujuan penataan ruang adalah terselenggaranya pemanfaatan ruang berwawasan lingkungan serta tercapainya pemanfaatan ruang yang berkualitas. ${ }^{51}$

Penekanan yang harus dilakukan terhadap pelestarian kearifan lokal yaitu dengan menjadikan norma adat dan tradisi budaya sebagai muatan dalam peraturan perundangundangan. Namun demikian, diperlukan kajian yang lebih mendalam dengan melibatkan lintas disiplin ilmu seperti ilmu sosial, hukum, dan budaya untuk melihat potensi-potensi kearifan lokal yang ada di setiap daerah. ${ }^{52}$

Upaya harmonisasi kearifan lokal terhadap aspek penataan ruang dapat berbentuk pelibatan masyarakat. Sebagai contoh, pelibatan tokoh adat dalam sosialisasi peraturan perundang-undangan di bidang penataan ruang. Tokoh-tokoh adat lebih mengetahui dan paham akan kearifan lokal yang ada pada suatu daerah. Selain itu, penyebaran informasi dengan ketentuan pelestarian budaya dan kawasan pusaka merupakan faktor penting lainnya dalam proses harmonisasi tersebut. Dengan demikian, regulasi penataan ruang dengan mempertimbangkan kearifan lokal yang ada secara efektif dapat dimanfaatkan oleh semua pihak. Pemanfaatan forum-forum tradisional atau organisasi kemasyarakatan dalam rangka proses konsultasi publik juga sama efektifnya dalam rangka upaya harmonisasi kearifan lokal dengan aspek pembinaan. ${ }^{53}$

Harmonisasi kearifan lokal dalam pelaksanaan penataan ruang juga dapat dilakukan dengan mempertahankan, melindungi, memelihara, dan mengembalikan fungsi kawasan pusaka budaya yang mengandung nilai sejarah, kearifan lokal, ilmu pengetahuan, dan kebudayaan serta mendorong kehidupan dan keberagaman aktivitas sosial seni dan budaya. Hal tersebut dalam arti luas,

\footnotetext{
51 BPHN, Perkembangan Pembangunan Hukum Nasional Tentang Hukum Tata Ruang, Jakarta, BPHN, 1996, hlm. 4.

52 Imam S. Ernawi, Makalah pada Seminar Nasional "Urban Culture, Urban Future: Harmonisasi Penataan Ruang dan Budaya Untuk Mengoptimalkan Potensi Kota".

53 Ibid.
} 
termasuk melalui penyediaan ruang dan fasilitas sehingga dapat mengangkat nilai fungsional, ekonomi, seni, budaya dan sejarah. Selain itu, dilakukan pula pengembangan public-private partnership melalui sistem kelembagaan, hukum dan manajemen perkotaan yang efektif dan profesional pada bangunan-bangunan konservasi atau pelestarian yang ada. Di sinilah, keterlibatan tokoh-tokoh adat juga sangat diperlukan sebagai proses pembelajaran akan kearifan lokal yang ada pada suatu daerah setempat. Penyelenggaraan penataan ruang dan kearifan lokal memiliki keterkaitan yang erat. Di tingkat daerah, kearifan lokal merupakan kunci penguatan penyelenggaraan penataan ruang. Undang-Undang Penataan Ruang telah memberi kewenangan kepada Pemerintah Provinsi dan Kota/Kabupaten untuk merencanakan penataan wilayah masing-masing sesuai dengan potensi sumber daya, karakteristik, dan budaya (kearifan lokal) daerah masingmasing. UUPR mengamanatkan mengenai pentingnya memperhatikan aspek kearifan lokal yang terkandung dalam sistem budaya dalam penyelenggaraan penataan ruang. Pemerintah perlu terus melakukan beberapa upaya pada berbagai tingkatan penyelenggaraan penataan ruang dalam rangka menjaga dan melestarikan nilai-nilai kearifan lokal dalam konteks

penataan ruang. Dalam proses penyusunan rencana tata ruang, peran masyarakat harus terlibat dalam seluruh proses dimulai dari tahap persiapan sampai pada tahap penetapan suatu rencana tata ruang wilayah. Pelaksanaan penyusunan rencana tata ruang diawali dengan identifikasi potensi dan masalah pembangunan yang tidak hanya mencakup perhatian pada masa sekarang, namun juga potensi dan masalah yang akan mengemuka di masa depan dengan tetap mempertimbangkan potensi wilayah serta budaya dari masing-masing daerah. ${ }^{54}$

Penggunaan ruang yang tidak sesuai dengan RTRW (Rencana Tata Ruang Wilayah) dapat menimbulkan dampak dan negatif yaitu tidak hanya terhadap keadaan sosial ekonomi perubahan ruang yang tak tertib bisa menimbulkan banjir, tanah longsor dan menurunnya kualitas air tanah. ${ }^{55}$

Permasalahan lain yang timbul yaitu pada sistem pemerintahan Indonesia, dimana saat ini terjadi perubahan dengan terdistribusinya kewenangan pemerintah pusat ke daerah dalam berbagai kegiatan pembangunan dalam bentuk sistem otonomi daerah. ${ }^{56}$ Konsep otonomi daerah membuat daerah diberi keleluasaan untuk mengelola dan memanfaatkan potensi sumber daya yang dimilikinya, terutama dalam pemanfaatan lahan di daerah. Otonomi penting untuk memperkokoh kultur dan nilai demokrasi seperti toleransi, bebas berpendapat, menghormati pendapat, terbuka dalam berkomunikasi serta memahami keanekaragaman dalam masyarakat. ${ }^{57} \mathrm{Hal}-$ hal tersebut penting untuk melindungi dan menjamin hak warga negara dalam pertarungan antara nilai ideal, nilai instrumental, dengan konteks sosial, ekonomi, budaya, termasuk alam. ${ }^{58}$ Seiring waktu, timbul problematika

\section{Ibid.}

55 Laporan Penelitian IPB, 2010, seperti dikutip dalam Laporan Penelitian Akhir BPHN Tahun 2016.

56 Otonomi mengandung pengertian pengaturan sendiri (selfregelling), pemerintahan sendiri (selfbestuur). Otonomi memiliki makna kemandirian, pelaksanaan otonomi memiliki prinsip keadilan dan penghormatan atas hak-hak asli, lihat Ade Saptomo, Hukum dan Kearifan Lokal, (Jakarta: Grasindo, 2010), hlm. 1.

57 Rusdianto Sesung, Hukum Otonomi Daerah, Refika Aditama, Bandung, 2013, hlm. 31.

58 Ibid. 
dalam pelaksanaan otonomi daerah, termasuk di antaranya terkait masalah penataan ruang, atas nama pembangunan dan otonomi maka pembangunan di daerah berlangsung masif namun ternyata dalam banyak hal terungkap pula adanya tentangan dari masyarakat, padahal seharusnya pembangunan itu untuk masyarakat. ${ }^{59}$ Pembangunan yang tak tepat guna serta merusak lingkungan dan melanggar tata ruang seringkali menjadi pemicu, hal yang seharusnya tidak terjadi karena sesungguhnya regulasi dan batasan-batasan serta acuan dalam penataan ruang sudah cukup jelas termasuk di antaranya dengan memperhatikan aspirasi masyarakat. ${ }^{60}$

Dalam konteks tersebut maka partisipasi dan peran serta masyarakat mutlak diperlukan, karena merekalah yang memahami betul daerah tempat mereka tinggal, dan mereka jualah yang akan terkena dampak dari penataan ruang. Pemikiran serta kearifan lokal yang mereka miliki perlu diformulasikan dalam bentuk regulasi formil.

Seiring dengan perkembangan era globalisasi, aspek kebudayaan juga mengalami perkembangan yang cukup pesat karena merupakan bagian penting dalam ilmu pengetahuan dan keterkaitannya dengan hubungan sosial kemanusiaan. Karena keterkaitan yang erat antara potensi budaya dan perencanaan tata ruang, diperlukan upaya untuk mengakomodasi nilai budaya lokal/adat istiadat ke dalam hukum positif, yaitu ke dalam regulasi penataan ruang. ${ }^{61}$ Upaya yang dapat mengakomodasi kearifan lokal dalam regulasi penataan ruang yaitu melalui proses adopsi, adaptasi.

Adopsi berarti mengakomodasikan apa saja yang terkandung di dalam kearifan lokal seutuhnya atau secara langsung ke dalam regulasi penataan ruang tanpa ada intervensi dari berbagai hal atau aspek. Sebagai contoh, di Nusa Penida Bali, kepercayaan keagamaan lokal menjadi acuan untuk upaya pelestarian lingkungan. Kebudayaan lokal termasuk kepercayaan agama dan perilaku masyarakat merupakan aspek yang penting dalam wujud penciptaan hubungan yang baik antara masyarakat atau suatu komunitas dengan alamnya. Oleh karena itu, sebagai contoh dari proses adopsi terkait dengan kearifan lokal, di Karang Kekeran misalnya, terdapat regulasi peruntukan lahan lokal yang mengatur pembangunan fisik tidak boleh dilakukan di dalam radius $0.5 \mathrm{~km}$ dari Pura Dhang Kahyangan. Penamaan daerah merupakan contoh lain yang merupakan bagian dari proses adopsi, dimana penamaan daerah menggunakan nama-nama dari penamaan zoning yang dahulu digunakan. Contohnya di Solo, Yogyakarta, nama-nama

59 Dengan kondisi seperti itu, pengendalian pemanfaatan ruang menjadi sangat penting dilakukan oleh pemerintah khususnya pemerintah daerah dalam upaya mengoptimalkan fungsi lahan sesuai dengan daya dukung lingkungan masing-masing. Lemahnya mekanisme pengendalian pembangunan merupakan salah satu kendala dalam menerapkan rencana tata ruang di daerah. Rencana tata ruang belum menjadi pedoman dalam penyusunan kebijakan, apalagi dalam perencanaan kegiatan pembangunan yang dilaksanakan setiap tahun jarang sekali memperhatikan rencana tata ruang untuk menentukan lokasi pembangunan yang tepat.

60 Dalam beberapa kasus, terbukti bahwa kearifan lokal yang tak dipatuhi justru merugikan pembangunan, seperti apa yang terjadi di Bandung, Perda tak mengacu pada konsep Sunda yang berorientasi pada perlindungan DAS (Daerah Aliran Sungai) dalam pengembangan pembangunan, akhirnya terjadi pencemaran dan banjir, hasil wawancara dengan Indra Perwira, dosen UNPAD dan anggota DPKLTS.

61 Imam S. Ernawi, Makalah pada Seminar Nasional "Urban Culture, Urban Future: Harmonisasi Penataan Ruang dan Budaya Untuk Mengoptimalkan Potensi Kota". 
suatu daerah (kelurahan atau kampung) mengadopsi dari nama-nama pen-zoning-an: kauman (daerah pesantren), kepatihan (daerah tempat para patih), dan jagalan (tempat menyembelih binatang sapi pada zaman dahulu kala). Proses akomodasi yang berikutnya yaitu dapat dilakukan dengan melakukan adaptasi, atau penyesuaian kearifan lokal yang dapat meliputi perubahan untuk menyesuaikan dan menghasilkan suatu perencanaan yang lebih baik. Pertanahan yang terkait hak ulayat dapat menjadi contoh proses adaptasi. Contohnya, Suku Baduy di Banten, mereka hidup turuntemurun di atas bidang tertentu dan membentuk wilayah kehidupan masyarakat Baduy yang terikat oleh tatanan hukum adat masyarakat Baduy dan seluruh anggota masyarakat harus mematuhi hukum adat tersebut. Pertanahan yang terkait hak ulayat sudah menjadi bagian dari kehidupan mereka. Mereka hidup dengan mengambil manfaat dari sumber daya alam di tanah-tanah tersebut. ${ }^{62}$

Melalui proses adaptasi, pemerintah mengakui dan menetapkan beberapa daerah di Banten, contohnya, Desa Kanekes sebagai hal ulayat masyarakat hukum adat Baduy, melalui beberapa peraturan daerah, seperti: 63

a. Peraturan Daerah Kabupaten Lebak Nomor 32 Tahun 2001 tentang Perlindungan Atas Hak Ulayat Masyarakat Baduy;

b. Peraturan Daerah Nomor 31 Tahun 2001 tentang Rencana Tata Ruang Wilayah Kabupaten Lebak;

c. Keputusan Bupati Lebak Nomor 590/ Kep.233/Huk/2002 tentang Penetapan Batas-batas Detail Tanah Ulayat Masyarakat
Adat Baduy di Desa Kanekes, Kecamatan Leuwidamar, Kabupaten Lebak.

Dengan ketetapan hukum tersebut dan proses adaptasi, hingga saat ini tanah ulayat masyarakat Baduy tetap terjaga keberadaannya, termasuk nilai-nilai budaya tetap dilestarikan, sehingga kearifan lokal dapat disinkronisasikan dengan proses adaptasi ke dalam regulasi penataan ruang. Dengan keanekaragaman budaya yang berlanjut melalui proses adaptasi yang merupakan fungsi kreatifitas yang berkelanjutan, budaya yang telah hilang keberadaannya dapat diupayakan kembali untuk dikembangkan. Bahkan, hal ini juga berlaku untuk cara pandang atau budaya baru, di mana akan ada proses adaptasi atau penyesuaian terhadap kondisi yang ada.

Undang-Undang Nomor 26 Tahun 2007 tentang Penataan Ruang (UUPR) telah memberi kewenangan kepada Pemerintah Provinsi dan Kota/Kabupaten untuk merencanakan penataan wilayah masing-masing sesuai dengan potensi sumber daya, karakteristik, dan budaya (kearifan lokal) daerah masingmasing. UUPR mengamanatkan mengenai pentingnya memperhatikan aspek kearifan lokal yang terkandung dalam sistem budaya dalam penyelenggaraan penataan ruang. Pemerintah perlu terus melakukan beberapa upaya pada berbagai tingkatan penyelenggaraan penataan ruang dalam rangka menjaga dan melestarikan nilai-nilai kearifan lokal dalam konteks penataan ruang. ${ }^{64}$

Penyelenggaraan penataan ruang dan kearifan lokal memiliki keterkaitan yang erat. Di tingkat daerah, kearifan lokal merupakan

62 Ibid.

63 Ibid.

64 Ibid. 
kunci penguatan penyelenggaraan penataan ruang. Undang-Undang Nomor 26 Tahun 2007 tentang Penataan Ruang (UUPR) telah memberi kewenangan kepada Pemerintah Provinsi dan Kota/Kabupaten untuk merencanakan penataan wilayah masing-masing sesuai dengan potensi sumber daya, karakteristik, dan budaya (kearifan lokal) daerah masingmasing. UUPR mengamanatkan mengenai pentingnya memperhatikan aspek kearifan lokal yang terkandung dalam sistem budaya dalam penyelenggaraan penataan ruang. Pemerintah perlu terus melakukan beberapa upaya pada berbagai tingkatan penyelenggaraan penataan ruang dalam rangka menjaga dan melestarikan nilai-nilai kearifan lokal dalam konteks penataan ruang. Dalam proses penyusunan rencana tata ruang, peran masyarakat harus terlibat dalam seluruh proses dimulai dari tahap persiapan sampai pada tahap penetapan suatu rencana tata ruang wilayah. Pelaksanaan penyusunan rencana tata ruang diawali dengan identifikasi potensi dan masalah pembangunan yang tidak hanya mencakup perhatian pada masa sekarang, namun juga potensi dan masalah yang akan mengemuka di masa depan dengan tetap mempertimbangkan potensi wilayah serta budaya dari masing-masing daerah. ${ }^{65}$

Dalam proses penyusunan rencana tata ruang, peran masyarakat harus terlibat dalam seluruh proses dimulai dari tahap persiapan sampai pada tahap penetapan suatu rencana tata ruang wilayah. Pelaksanaan penyusunan rencana tata ruang diawali dengan identifikasi potensi dan masalah pembangunan yang tidak hanya mencakup perhatian pada masa sekarang, namun juga potensi dan masalah yang akan mengemuka di masa depan dengan tetap mempertimbangkan potensi wilayah serta budaya dari masing-masing daerah. Karena adanya hubungan yang erat antara budaya dan kota, di mana kota merupakan suatu bentuk dari perwujudan fisik dan spasial atas artikulasi budaya masyarakat, upaya mengakomodasikan aspek budaya ke dalam perencanaan tata ruang perlu diperhatikan dengan baik. Dalam rangka mengharmonisasikan, menjaga, dan melestarikan nilai-nilai kearifan lokal dalam konteks penataan ruang, pemerintah perlu melakukan beberapa upaya pada berbagai aspek pada tingkatan penyelenggaraan penataan ruang yang meliputi pengaturan, pembinaan, pelaksanaan, dan pengawasan penataan ruang. ${ }^{66}$ Operasionalisasi kebijakan dan strategi dalam rangka pelestarian dan pengembangan kearifan lokal harus diupayakan secara lebih terpadu dan berkelanjutan dengan mensinergikan antara aspek budaya serta aspek strategis lainnya melalui pengarus-utamaan prinsip-prinsip dan nilai budaya daerah dalam proses penyelenggaraan penataan ruang di tingkat pemerintah pusat, provinsi, kabupaten dan kota sesuai dengan semangat desentralisasi dan otonomi daerah.

\section{Penutup}

Masyarakat beserta kearifan lokalnya diakui eksistensinya dalam penataan ruang, bahkan peranannya diakomodir secara eksplisit dalam peraturan perundang-undangan. Dalam tataran teknis maka kearifan lokal ini harus

\footnotetext{
65 Imam S. Ernawi, Makalah pada Seminar Nasional "Urban Culture, Urban Future: Harmonisasi Penataan Ruang dan Budaya Untuk Mengoptimalkan Potensi Kota”.

66 Ibid.
} 
diformulasikan ke dalam bentuk peraturan perundang-undangan setingkat peraturan daerah, bahkan di beberapa daerah sudah ada peraturan daerah yang eksis dan secara nyata mengakomodir serta selaras dengan kearifan lokal masyarakat. Upaya yang dapat dilakukan untuk mengakomodir kearifan lokal ke dalam peraturan daerah adalah proses adopsi dan adaptasi. Dalam proses penyusunan rencana tata ruang, peran masyarakat harus terlibat dalam seluruh proses dimulai dari tahap persiapan sampai pada tahap penetapan suatu rencana tata ruang wilayah. Partisipasi aktif menjadi kunci agar masyarakat dapat berperan secara nyata dan bukan hanya sekedar aktivisme prosedural formiil dalam pembentukan regulasi di daerah. Melalui tahapan partisipasi ini pula kearifan lokal masyarakat akan dapat terakomodir dengan baik, partisipasi dalam pembentukan regulasi daerah dijamin oleh Undang-Undang. Peraturan daerah yang mengakomodir kearifan lokal masyarakat dapat dijadikan indikator dan dasar hukum untuk menunjukkan bahwa kesatuan masyarakat hukum adat itu masih eksis.

\section{Daftar Pustaka}

\section{Buku}

Anshori,AbdulGofurdanSobirin Malian,Membangun Hukum Indonesia Pidato Pengukuhan Guru Besar IImu Hukum, (Yogyakarta: Kresi Total Media, 2008)

Bakri, Muhammad, Hak Menguasai Tanah Oleh Negara, (Malang: UB Press, 2011)

Geriya, I Wayan, Konsep dan Strategi Revitalisasi Kearifan Lokal, (Denpasar: UPT Penerbit Universitas Udayana, 2007)

Halim, Hamzah dan Kemal Redindo, Cara Praktis Menyusun dan Merancang Peraturan Daerah, (Jakarta: Kencana Prenada Media Group, 2009)

Huntington, Samuel dan Joan Nelson, Partisipasi Politik di Negara Berkembang, (Jakarta: Rineka Cipta, 1994)
Ibrahim, Anis, Legislasi dan Demokrasi (Malang: InTrans Publishing, 2008)

Isra, Saldi, Pergeseran Fungsi Legislasi, (Jakarta: PT. Raja Grafindo Persada, 2010)

Sumardjono, Maria, Pengaturan SDA di Indonesia, Antara yang Tersurat dan Tersirat, (Yogyakarta: Gadjah Mada University, 2011)

Marzuki, Peter Mahmud, Penelitian Hukum, (Jakarta: Kencana, 2010)

Marfai, Muh Aris, Pengantar Etika Lingkungan dan Kearifan Lokal, (Yogyakarta: Gajah Mada University Press, 2012)

MD, Mahfud, Politik Hukum di Indonesia, (Jakarta: PT. Raja Grafindo Persada, 2009),

Juniarso, Ridwan dan Achmad Sodik, Hukum Tata Ruang: Dalam Konsep Kebijakan Otonomi Daerah, (Bandung: Nuansa, 2008)

Santosa, Mas Achmad, Good Governance dan Hukum Lingkungan, (Jakarta: ICEL, 2001)

Santosa, Mas Achmad dan Arimbi HP, Peran Serta Masyarakat Dalam Pengelolaan Lingkungan, (Jakarta: WALHI dan YLBHI, 1933)

Saptomo, Ade, Hukum dan Kearifan Lokal, (Jakarta: Grasindo, 2010)

Sesung, Rusdianto, Hukum Otonomi Daerah, (Bandung: Refika Aditama, 2013)

Siahaan, Pataniari, Politik Hukum Pembentukan Undang-Undang pasca Amandemen UUD 1945, (Jakarta: Konpress, 2012)

Soekanto, Soerjono dan Sri Mamudji, Penelitian Hukum Normatif: Suatu Tinjauan Singkat, (Jakarta: Raja Grafindo Persada, 2001)

Suhartini, Kearifan Lokal dan Konservasi Keanekaragaman Hayati, (Yogyakarta: UGM, 2009)

Suja, Wayan, Kearifan Lokal Sains Asli Bali, (Surabaya: Paramita, 2010)

Wijana Nyoman, Pengelolaan Lingkungan Hidup, (Yogyakarta: Plantaxia, 2016)

\section{Makalah/Artikel/Laporan/Hasil Penelitian}

Nugraheni, Konservasi Hutan dan Pola Pertanian Tradisional Masyarakat Baduy di Banten, Jurnal Studi Indonesia Vol. 15 No. 1, Maret (2005)

Sartini, Menggali Kearifan Lokal Nusantara Sebuah Kajian Filsafati, Jurnal Filsafat, Jilid 37, Nomor 2, Agustus (2004) 


\section{Peraturan}

Undang-Undang Dasar Negara Republik Indonesia Tahun 1945

Peraturan Pemerintah Nomor 68 Tahun 2010 tentang Bentuk dan Tata Cara Peran Masyarakat Dalam Penataan Ruang

Undang Undang Nomor 26 Tahun 2007 tentang Penataan Ruang 
"Halaman ini dikosongkan" 